THE TRIALS OF ACADEME 

Amy Gajda

\section{The Trials of Academe}

The New Era of Campus Litigation

HARVARD UNIVERSITY PRES S

Cambridge, Massachusetts, and London, England 2009 
Copyright $\odot 2009$ by the President and Fellows of Harvard College All rights reserved

Printed in the United States of America

Library of Congress Cataloging-in-Publication Data

Gajda, Amy.

The trials of academe : the new era of campus litigation / Amy Gajda. p. $\mathrm{cm}$.

Includes bibliographical references and index.

ISBN 978-0-674-03567-6 (alk. paper)

1. Universities and colleges—Law and legislation-United States. I. Title.

KF4225.G35 2009

344.73'074-dc22 2009022123 
This book is for my father, Leo Gajda, a scholar at heart who could only dream of college. 
